\title{
Mechanisms of anesthesia: past, present, and a glimpse into the future
}

\author{
Keith W. Miller, DPhil · Beverley A. Orser, MD, PhD • \\ Sheldon H. Roth, PhD
}

Published online: 17 December 2010

(C) Canadian Anesthesiologists' Society 2010

The 8th International Conference on Mechanisms of Anesthesia (MAC) was held in Toronto from June 16-18, 2010. Meetings in this series bring together clinicianscientists and full-time scientists in order to enhance our understanding of the mechanisms of action of general anesthetics. Many participants have inquired as to the origins of this series, which has now been in existence for 36 years. In this Editorial, we review the history of the MAC conference and the evolution of scientific discovery related to anesthetic mechanisms and finally, propose future directions of inquiry.

K. W. Miller, DPhil

Department of Anesthesia, Critical Care and Pain Medicine,

Massachusetts General Hospital, Boston, MA, USA

K. W. Miller, DPhil

Department of Biological Chemistry and Molecular

Pharmacology, Harvard Medical School, Boston, MA, USA

\section{B. A. Orser, $\mathrm{MD}, \mathrm{PhD}(\square)$}

Departments of Anesthesia and Physiology,

University of Toronto, Rm. 3318, Medical Sciences Building,

1 King's College Circle, Toronto,

ON M5S 1A8, Canada

e-mail: beverley.orser@utoronto.ca

B. A. Orser, $\mathrm{MD}, \mathrm{PhD}$

Department of Anesthesia, Sunnybrook Health Sciences Centre,

Toronto, ON, Canada

\section{S. H. Roth, PhD}

Departments of Physiology and Pharmacology and Anesthesiology, Hotchkiss Brain Institute,

University of Calgary, Calgary, AB, Canada

\section{History of the MAC conference}

Dr. B. Raymond Fink, a British anesthesiologist, was the originator of the MAC conferences. Dr. Fink initially worked in South Africa, but he immigrated to the United States to avoid living under the apartheid regime and joined the faculty at Columbia University in 1950. At that time, the Department of Anesthesia, under Emanuel (Manny) Papper, was becoming the premier academic anesthesia department in the country and was destined to produce many leading academics. In 1964, Dr. Fink moved from Columbia University to the University of Washington's School of Medicine in Seattle, where he stayed for the remainder of his career. He was a terrific companion and colleague; he was an exceptionally hospitable, compassionate, and curious individual with a unique sense of humour. Those who wish to appreciate the flavour of his personality should read the announcement accompanying his American Society of Anesthesiologists' award in 1987 and an insightful obituary. ${ }^{1,2}$ Dr. Fink's interest in and enthusiasm for science and innovation continued throughout his life, and he remains an inspiration to those who knew him.

Ray played an active role in an era when the scientific foundations of anesthesiology were being established. The late Burnell Brown (Chair, Anesthesiology, University of Arizona College of Medicine, Tuscon) wrote the following in his review of a publication that emanated from an early meeting, "What about the clinician? Is there anything for him to gain? The answer is simple and trite: yes, there is, knowledge. Anesthesiology is not just a technical art; it is a dedicated scientific method of human biology which constitutes a distinct discipline. The more we understand theory; our clinical judgment must consequently be honed." 
There is some debate regarding the number of MAC conferences previously held. In his foreword to the 1984 meeting, ${ }^{4}$ Dr. Ray Fink wrote,

"... continuing a series that began at the University of Washington where I hosted two, four, or five previous ones, depending on how far back one wishes to count. At that, Seattle took up where Paris left off in 1951."

However, the first international conference was held in 1974, so we count from there, and four of the possible five meetings in Seattle that Ray mentioned are included in the Table.

The 1974 meeting, the International Conference on Molecular Mechanisms of Anesthesia, was held in the outskirts of Seattle in a former monastery. Dr. Fink later wrote regarding that gathering, ${ }^{5}$ "The irresistible excitement of new ideas permeates this field and explains why so many scientists were willing to undertake long and uncompensated journeys...." The resulting publication listed 80 contributors, 12 of whom were from Europe. The format of the gathering was similar to a Gordon Conference with its pleasant afternoon walks; however, this informality was short-lived. In 1979, the second international conference was held in very cramped quarters in a Seattle hotel, where participants gave their presentations in marathon sessions. Once again, Dr. Fink was able to attract eminent speakers from around the globe. There were 70 contributors to the volume he published the following year, ${ }^{6} 14$ from Europe and the remainder from North America. The mantle was then passed to Sheldon Roth and Keith Miller who organized three conferences on the
University of Calgary campus. Long intervals were deliberately scheduled between the conferences to allow for significant advances to occur in the interim and to make it worthwhile for internationally recognized researchers to pay their own expenses to attend. Although the meetings retained Dr. Fink's intense three-day format, the novelty of bars on campus (to visitors from the United States at least) led to unscheduled social activities. The final evening of each Calgary conference culminated with a western barbecue at a ranch (an event designed to prevent attendees from departing early). At the third Calgary meeting, a conference logo was introduced and Plenum Press agreed to publish the proceedings. More than 600 copies of the publication were sold, an impressive number for such a small discipline but, unfortunately, far below the publisher's break-even point.

The fourth conference was held under the auspices of the New York Academy of Sciences, which solved the problem of finding a publisher. For the first time, the proceedings were published in a widely available journal that would be indexed for easy access. Thanks to the intervention of Bill Winlow and Chris Richards, publication for the 1997 meeting was also readily available. Since then, British and Canadian anesthesia journals have shouldered responsibility to ensure selected contributions have access to publication. The fourth meeting was unusual for two reasons; it was the longest of the conferences to date, and it was held jointly with a group of alcohol researchers. Emanuel Rubin served as an indispensable mediator between the two disciplines that have much in

Table History of the International Conferences on Mechanisms of Anesthesia

\begin{tabular}{|c|c|c|c|}
\hline Date & Title & Where & Organizers $^{\mathrm{A}}$ \\
\hline 1951 & Mécanisms de la Narcose ${ }^{7}$ & Paris & Fink \\
\hline 1967 12-13 May & Toxic Effects of Anesthetics ${ }^{8}$ & Seattle, USA & Fink \\
\hline 1970 11-12 May & Cellular Biology and Toxicity of Anesthetics ${ }^{9}$ & Seattle USA & Fink \\
\hline 1974 12-14 June & $\begin{array}{l}\text { International Conference on Molecular Mechanisms } \\
\text { of Anesthesia }\end{array}$ & Seattle, USA & Fink \\
\hline 1979 14-16 June & $\begin{array}{l}2^{\text {nd }} \text { International Research Conference on Molecular } \\
\text { Mechanisms of Anesthesia }\end{array}$ & Seattle, USA & Fink \\
\hline 1984 13-15 June & $\begin{array}{l}3^{\text {rd }} \text { International Conference on Molecular \& } \\
\text { Cellular Mechanisms of Anesthesia }{ }^{4}\end{array}$ & Calgary, Canada & Roth \& Miller \\
\hline 1990 25-28 June & $\begin{array}{l}\text { Molecular \& Cellular Mechanisms of Alcohol and } \\
\text { Anesthetics }{ }^{10}\end{array}$ & Calgary, Canada & Roth, Rubin \& Miller \\
\hline 1997 18-20 June & $\begin{array}{l}5^{\text {th }} \text { International Conference on Molecular \& } \\
\text { Cellular Mechanisms of Anesthesia }{ }^{11}\end{array}$ & Calgary, Canada & Roth \& Miller \\
\hline 2001 28-30 June & $\begin{array}{l}6^{\text {th }} \text { International Conference on Molecular \& Basic } \\
\text { Mechanisms of Anesthesia }\end{array}$ & Bonn, Germany & Urban \& Richards (Roth, \& Miller) \\
\hline 2005 26-28 Feb & $\begin{array}{l}7^{\text {th }} \text { International Conference On Basic and Systemic } \\
\text { Mechanisms of Anesthesia }\end{array}$ & Nara, Japan & $\begin{array}{l}\text { Mashimo \& Ogli (Miller, Roth, Richards } \\
\quad \text { \& Urban) }\end{array}$ \\
\hline 2010 16-18 June & $\begin{array}{l}\text { 8th International Conference on the Mechanisms of } \\
\text { Anesthetics }\end{array}$ & Toronto, Canada & $\begin{array}{l}\text { Orser, Miller, Roth (Urban, Maze, Hirota, } \\
\text { Aguayo) }\end{array}$ \\
\hline
\end{tabular}

A The local organizers' names are given, with the international committee's names noted in parenthesis where appropriate 
common. The National Institute on Alcohol Abuse and Alcoholism was extremely generous in its support, which facilitated bringing in eminent keynote speakers to begin each symposium.

The fifth conference was the last to be held in Calgary. At that point, an international committee was established, and meetings began to rotate among European, Asian, and North American locations. The sixth conference, the first to be held in Europe, was organized by Bernd Urban (assisted by his entire family, it seemed) and Chris Richards. Perhaps Bernd's sons coined the sticky acronym, MAC (Mechanisms of Anesthesia Conference), but then again it was 2001. The Gustav-Stresemann-Institut in Bonn provided a selfcontained setting that maintained the established character of the meeting. The seventh conference, the first to be held in Asia, was organized by Kenji Ogli with assistance from Takashi Mashimo and Ichiro Uchida. The meeting was held at the elegant Nara-Ken New Public Hall in Nara National Park in the city of Nara, Japan, a World Heritage Site. Memorable in many ways, this was the first meeting to garner attendees from every continent. The eighth MAC conference returned to North America and was held in Toronto with Dr. Beverley Orser as the local organizer.

Attendance has grown over the years, with close to 150 attendees at the first Calgary meeting (the third in the series). The high point was the 1990 meeting, which attracted more than 250 investigators active in anesthetics or alcohol research. There were close to 150 attendees at the Nara meeting despite the long travel distances, and about 200 attendees took part at the most recent meeting. Clinician-scientists make up about half of the attendees at most of the meetings.

Funding has always been a challenge, and considerable faith has often been required on the part of organizers. Over the years, many individual departments of anesthesia have provided funds and have supported the attendance of their departmental staff. Crucial support has come at various times from the Alberta Heritage for Medical Research, the National Institute on Alcohol Abuse and Alcoholism, Deutsche Forschungsgemeinschaft, Bonn, and many pharmaceutical companies whose contributions are acknowledged in the individual proceedings. The latter support has been crucial during the planning phase, but it has always been the popularity of the conferences that has allowed them to break-even.

\section{Current status of research on the mechanisms of general anesthetics}

Over the past four decades, the scientific foundations of the mechanisms of anesthesia have evolved dramatically, from the Meyer-Overton controversies to the $\mathrm{GABA}_{\mathrm{A}}$ receptor orthodoxy to a more mature realization that there is no unitary hypothesis at the molecular level. This recognition should come as no surprise. Even drugs that act in the nanomolar range of concentrations have secondary targets, so anesthetic drugs, which act primarily in the high micromolar range, are likely to have many targets. Indeed, clinicians' everyday observations of their patients' physiology attest to the multiplicity of drug actions.

At the molecular level, researchers are forging ahead with studies of channels. Photolabelling and site-directed mutagenesis have been used to locate binding sites and to understand the allosteric interaction between general anesthetics and channel gating in a few targets. During the previous two MAC conferences, the structure of ligandgated ion channels has been revealed, and the binding of anesthetics to ion channels has been observed through crystallography for the first time. At the same time, mice with engineered ion channels have been used to show the link between the molecular and the physiological, at least for the most potent intravenous agents. The less potent agents have been more refractory to elucidation, perhaps because their action is distributed over many targets, a continuing challenge to developing a molecular understanding.

Progress is also apparent beyond the cellular level, as physiologists exploit their knowledge of channel behaviour to deepen their understanding of network behaviour under anesthesia. Advances in understanding individual networks will likely precede an overall understanding of the larger issue, consciousness. Investigating how general anesthetics ablate consciousness remains an active field, but it is hampered by the lack of a physiologic definition of consciousness. Given that we now believe that different classes of general anesthetics act on different spectrums of receptors and channels, we can no longer be certain that anesthetic-induced unconsciousness is a single state. Faced with such conundrums, some researchers have turned to quantifiable entities, such as sleep and memory. It is certain that this area of inquiry will remain central to the field for many decades to come.

A new feature of the MAC 2010 conference was the concern over deleterious actions of general anesthetics. At a practical level, the safety of the patient is far more dependent on the off-target effects of general anesthetics than on their ability to cause anesthesia. Anesthesia is safe only because it is administered by highly trained professionals devoted to administering anesthesia. The agents themselves have abysmal therapeutic ratios. Gaining an understanding of the mechanisms of anesthetic-induced respiratory depression, for example, is arguably more important than understanding consciousness. Indeed, a new area of research has grown robustly out of the fears that general anesthetics may cause various forms of cognitive dysfunction or may have adverse effects on the developing 
brain. It is unclear whether these effects are caused by anesthetics or surgery, but the implications are so farreaching that further research is inevitable.

\section{Future directions}

The expectations of patients and physicians have increased in the past several decades, even though anesthesia-related mortality has remained constant. Patients now fully assume that they will emerge from anesthesia without recollection of the event and then rapidly return to normal physiological function. Thus, the growing understanding of the mechanisms by which general anesthetics act at the molecular and cellular level provides an essential foundation for addressing the off-target mechanisms that delay or limit recovery. At the same time, we are moving closer to integrating knowledge gained at the molecular level to provide a better understanding of neuronal network behaviour. Such insights move us closer to understanding the cellular basis of consciousness and may lead ultimately to better monitoring of anesthetic depth. This series of conferences attracts scientists and clinician-scientists in equal numbers and is ideally suited to further both the longterm goal of increased knowledge and the more pressing translational issues that face clinical practice today.

The mechanistic research presented at the MAC 2010 conference serves three important functions. First, it moves us closer to drug discovery by identifying key therapeutic receptors as well as off-target sites of action. This knowledge will provide a basis for developing novel anesthetic drugs with higher therapeutic indices, the next major hurdle in advancing anesthesia safety. Second, mechanistic studies ensure that we optimize the clinical use of currently available anesthetics through an understanding of their actions on therapeutic and other targets. Finally, anesthetics remain powerful probes that can be used to perturb neurons and networks reversibly in order to gain insights into the biology of the central nervous system.

Despite the significant advances presented at the MAC conference in Toronto, much work remains to be done. Patients expect the best science to be brought to bear on anesthesia-related clinical problems. The responsibility to meet this expectation rests firmly on the shoulders of the academic departments of anesthesia. These departments must continue to train young scientists and clinician-scientists so that fundamental research can address the problems that patients face. The challenge for these departments is two-fold. First, to find the resources to support their investigators and second, to create an environment that fosters the pursuit of knowledge and innovation.

\section{Les mécanismes de l'anesthésie: le passé, le présent, et un aperçu de l'avenir}

La $8^{\mathrm{e}}$ Conférence internationale sur les mécanismes de l'anesthésie (MAC) s'est tenue à Toronto du 16 au 18 juin 2010. Les congrès de cette série réunissent des chercheurs cliniciens et des chercheurs à temps plein; leur but est d'améliorer notre compréhension des mécanismes d'action des anesthésiques généraux. La série existe depuis 36 ans, et plusieurs participants s'interrogent sur ses origines.

\section{L'histoire de la conférence MAC}

Dr. B. Raymond Fink, un anesthésiologiste britannique ayant exercé en Afrique du Sud, est le père fondateur de ces conférences. Dr. Fink immigra aux États-Unis afin de ne pas vivre sous le régime de l'apartheid, et il devint membre du corps professoral de la Columbia University en 1950. À cette époque, sous la direction éclairée d'Emanuel (Manny) Papper, ce département d'anesthésie était en passe de devenir le meilleur département d'anesthésie universitaire $\mathrm{du}$ pays et allait former plusieurs universitaires reconnus. Dr. Fink quitta l'Université de Columbia en 1964 pour s'établir à l'École de médecine de l'Université de Washington à Seattle, où il demeura pour le restant de sa carrière. Dr. Raymond Fink était un ami et collègue extraordinaire de nombreuses façons: à la fois généreux et accueillant, c'était une personne pleine de compassion et de curiosité qui possédait un sens de l'humour unique. Nous invitons ceux et celles qui souhaitent se faire une idée plus précise de sa personnalité à lire l'annonce accompagnant le Prix de l'ASA en 1987 et son avis de décès. ${ }^{1,2}$ L'intérêt et l'enthousiasme du Dr. Fink pour la science et l'innovation l'ont accompagné sa vie durant, et il est encore un modèle pour tous ceux qui l'ont connu.

La carrière du Dr. Fink a coïncidé avec l'époque où l'on posait les fondements scientifiques de l'anesthésiologie. Pour citer feu Burnell Brown (président du département d'anesthésiologie de l'École de médecine de l'Université de l'Arizona, Tucson), dans le compte-rendu qu'il fit d'une publication issue de l'une des premières réunions ${ }^{3}$ : «Et le clinicien? Est-ce qu'il y gagne quelque chose? La réponse est simple et banale: oui - la connaissance. L'anesthésiologie n'est pas seulement un art technique; c'est une méthode scientifique sérieuse de la biologie humaine, et une discipline en soi. Plus nous comprenons la théorie, plus notre jugement clinique sera aiguisé. » 
Le nombre de conférences MAC à avoir eu lieu est sujet de débat. Dans son avant-propos à la conférence de $1984,{ }^{4}$ Dr. Ray Fink écrivait:

«... afin de poursuivre une série qui a vu le jour à l'Université de Washington où j'en ai déjà organisées deux, quatre ou cinq, selon jusqu'à quel moment on souhaite remonter. Cela étant dit, Seattle a repris le flambeau là où Paris l'avait laissé en 1951. »

Toutefois, la première conférence d'envergure internationale s'est tenue en 1974 , et c'est là que commence notre décompte. Quatre des cinq congrès possibles de Seattle que le Dr. Fink mentionne sont citées dans le tableau.

Le congrès de 1974, intitulé Conférence internationale sur les mécanismes moléculaires de l'anesthésie, a eu lieu dans la banlieue de Seattle, dans un ancien monastère. À propos de ce congrès, Dr. Fink allait plus tard écrire $^{5}$ : «L'enthousiasme communicatif provoqué par de nouvelles idées imprègne ce domaine. Ceci explique pourquoi les scientifiques sont si nombreux à bien vouloir entreprendre ce long déplacement à leurs propres frais... ». La publication qui résulte de ce congrès cite 80 contributeurs, dont 12 provenant d'Europe. Le format $\mathrm{du}$ congrès rappelait celui de la Gordon Conference, comprenant des promenades dans l'après-midi, mais ce côté informel a vite disparu. La deuxième conférence, en 1979, s'est tenue dans des salles exiguës dans un hôtel de Seattle. Les participants présentèrent leurs travaux dans des sessions dignes d'un marathon. Une fois de plus, Dr. Fink est parvenu à attirer des conférenciers réputés des quatre coins de la planète. Soixante-dix contributeurs sont cités dans le volume qu'il fit paraitre l'année suivante, ${ }^{6}$ quatorze en provenance d'Europe et les autres d'Amérique du Nord. L'organisation de la conférence a par la suite été remise à Sheldon Roth et Keith Miller, qui ont accueilli trois conférences sur le campus de l'Université de Calgary. L'intervalle entre les conférences était intentionnellement long, afin qu'il y ait suffisamment de temps pour que des

Tableau Histoire des Conférences internationales sur les mécanismes de l'anesthésie

\begin{tabular}{|c|c|c|c|}
\hline Date & Titre & Lieu & Organisateurs $^{\mathrm{A}}$ \\
\hline 1951 & Mécanismes de la narcose ${ }^{7}$ & Paris & Fink \\
\hline $196712-13$ mai & $\begin{array}{l}\text { Toxic Effects of Anesthetics }{ }^{8} \text { (Les effets toxiques des } \\
\text { anesthésiques) }\end{array}$ & Seattle, États-Unis & Fink \\
\hline $197011-12$ mai & $\begin{array}{l}\text { Cellular Biology and Toxicity of Anesthetics }{ }^{9} \text { (Biologie } \\
\text { cellulaire et toxicité des anesthésiques) }\end{array}$ & Seattle États-Unis & Fink \\
\hline 1974 12-14 juin & $\begin{array}{l}\text { International Conference on Molecular Mechanisms of } \\
\text { Anesthesia }{ }^{5} \text { (Conférence internationale sur les mécanismes } \\
\text { moléculaires de l'anesthésie) }\end{array}$ & Seattle, États-Unis & Fink \\
\hline 1979 14-16 juin & $\begin{array}{l}2^{\text {nd }} \text { International Conference on Molecular Mechanisms of } \\
\text { Anesthesia }{ }^{6}\left(2^{\mathrm{e}} \text { Conférence internationale sur les }\right. \\
\text { mécanismes moléculaires de l'anesthésie })\end{array}$ & Seattle, États-Unis & Fink \\
\hline $198413-15$ juin & $\begin{array}{l}3^{\text {rd }} \text { International Conference on Molecular \& Cellular } \\
\text { Mechanisms of Anesthesia }{ }^{4}\left(3^{\mathrm{e}} \text { Conférence internationale }\right. \\
\text { sur les mécanismes moléculaires et cellulaires de } \\
\text { l'anesthésie) }\end{array}$ & Calgary, Canada & Roth \& Miller \\
\hline $199025-28$ juin & $\begin{array}{l}\text { Molecular \& Cellular Mechanisms of Alcohol and } \\
\text { Anesthetics }{ }^{10} \text { (Les mécanismes moléculaires et cellulaires } \\
\text { de l'alcool et des anesthésiques) }\end{array}$ & Calgary, Canada & Roth, Rubin \& Miller \\
\hline $199718-20$ juin & $\begin{array}{l}5^{\text {th }} \text { International Conference on Molecular \& Cellular } \\
\text { Mechanisms of Anesthesia }{ }^{11}\left(5^{\mathrm{e}} \text { Conférence internationale }\right. \\
\text { sur les mécanismes moléculaires et cellulaires de } \\
\text { l'anesthésie) }\end{array}$ & Calgary, Canada & Roth \& Miller \\
\hline $200128-30$ juin & $\begin{array}{l}6^{\text {th }} \text { International Conference on Molecular \& Basic } \\
\text { Mechanisms of Anesthesia }{ }^{12,13}\left(6^{\mathrm{e}} \text { Conférence }\right. \\
\text { internationale sur les mécanismes moléculaires et basiques } \\
\text { de l'anesthésie) }\end{array}$ & Bonn, Allemagne & $\begin{array}{l}\text { Urban \& Richards (Roth, \& } \\
\text { Miller) }\end{array}$ \\
\hline 2005 26-28 février & $\begin{array}{l}7^{\text {th }} \text { International Conference on Basic and Systemic } \\
\text { Mechanisms of Anesthesia }{ }^{14}\left(7^{\mathrm{e}} \text { Conférence internationale }\right. \\
\text { sur les mécanismes basiques et systémiques de l'anesthésie) }\end{array}$ & Nara, Japon & $\begin{array}{l}\text { Mashimo \& Ogli (Miller, Roth, } \\
\text { Richards \& Urban) }\end{array}$ \\
\hline $201016-18$ juin & $\begin{array}{l}\text { 8th International Conference on the Mechanisms of } \\
\text { Anesthetics ( } 8^{\mathrm{e}} \text { Conférence internationale sur les } \\
\text { mécanismes des anesthésiques) }\end{array}$ & Toronto, Canada & $\begin{array}{l}\text { Orser, Miller, Roth (Urban, Maze, } \\
\text { Hirota, Aguayo) }\end{array}$ \\
\hline
\end{tabular}

${ }^{\text {A }}$ Les noms des organisateurs locaux sont donnés, les noms du comité international étant notés entre parenthèses le cas échéant. 
progrès importants puissent être accomplis entre-temps ce qui rendait les conférences d'autant plus intéressantes pour les conférenciers internationaux et les motivait à défrayer leurs propres coûts. Bien que les conférences aient maintenu le format de trois jours intensifs proposé à l'origine par le Dr. Fink, la nouveauté - du moins pour les visiteurs provenant des États-Unis - résidait dans les bars situés sur le campus, qui ont permis la tenue d'activités de rencontre non planifiées. Le point culminant de chacune des conférences de Calgary était un barbecue de style western organisé dans un ranch le dernier soir, un événement dont le but était d'éviter que les participants ne quittent la conférence plus tôt! Lors de la troisième conférence, un logo a vu le jour et Plenum Press a décidé de publier les comptes-rendus des conférences. Plus de 600 exemplaires ont été vendus - un nombre impressionnant compte tenu de la taille de la discipline, mais malheureusement bien en-deçà du seuil de rentabilité de l'éditeur.

La quatrième conférence s'est tenue sous les auspices de l'Académie des sciences de New York, ce qui a résolu le problème de l'éditeur. Pour la première fois, les comptes-rendus ont été publiés dans une revue bénéficiant d'une distribution importante, grâce à laquelle ils seraient indexés afin d'en faciliter l'accès. Une publication facilement accessible du congrès de 1997 a de nouveau été obtenue grâce à l'intervention de Bill Winlow et de Chris Richards. Par la suite, les revues d'anesthésie britanniques et canadiennes ont endossé cette tâche, ce qui a permis de publier certaines contributions afin qu'elles soient aisément accessibles. La quatrième conférence était particulière pour deux raisons: il s'agit de la plus longue conférence à date, et elle a été organisée conjointement avec un groupe de chercheurs sur 1'alcool. Emanuel Rubin a joué le rôle indispensable d'intermédiaire entre les deux disciplines qui ont tellement de points communs. L'Institut américain contre l'abus d'alcool et l'alcoolisme (National Institute on Alcohol Abuse and Alcoholism) a offert un soutien extrêmement généreux à la conférence, ce qui a permis d'inviter des conférenciers renommés pour animer chacun des symposiums.

Le cinquième congrès fut le dernier à être organisé à Calgary. Un comité international a alors été mis sur pied, et les réunions ont été organisées à tour de rôle en Europe, en Asie et en Amérique du Nord. Le sixième congrès, le premier à se tenir en Europe, a été organisé par Bernd Urban (apparemment avec l'aide de toute sa famille) et Chris Richards. Il se peut que l'acronyme accrocheur de MAC (Mechanisms of Anesthesia Conference) provienne de l'esprit des fils de Bernd Urban, mais il a été repris en 2001. L'Institut Gustav-Stresemann à Bonn a permis l'organisation d'une conférence sur un site autonome, ce qui a maintenu le caractère établi de la conférence. La septième conférence fut la première à être organisée en
Asie. Sous l'égide de Kenji Ogli, avec l'aide de Takashi Mashimo et Ichiro Uchida, la conférence s'est tenue dans la nouvelle salle publique Nara-Ken, située dans le parc national de Nara de la ville éponyme au Japon, un site du patrimoine mondial de l'UNESCO. Mémorable de multiples façons, cette conférence fut la première à attirer des participants de tous les continents. La huitième conférence MAC est revenue en Amérique du Nord et a eu lieu à Toronto grâce aux talents d'organisatrice de l'une de nos consœurs, la Dre Beverley Orser.

La participation a augmenté au fil du temps. Près de 150 personnes ont participé à la première réunion à Calgary (la troisième de la série). La conférence la plus populaire en termes de participation fut celle de 1990, qui attira plus de 250 chercheurs travaillant dans le domaine de la recherche sur les anesthésiques ou sur l'alcool. La conférence de Nara a attiré quelques 150 participants, malgré la distance à parcourir. La dernière conférence a pu compter sur la participation d'environ 200 personnes. Lors de la plupart des conférences, environ la moitié des participants étaient des chercheurs cliniciens.

Le financement est à chaque occasion un nouveau défi, et la foi joue souvent un rôle important pour les organisateurs. Au fil des années, plusieurs départements d'anesthésie ont injecté des fonds et soutenu financièrement leur personnel afin qu'il puisse participer aux conférences. Des financements clés ont été généreusement offerts à un moment donné par l'Alberta Heritage Foundation, le National Institute on Alcohol Abuse and Alcoholism, la Deutsche Forschungsgemeinschaft de Bonn et nombre de compagnies pharmaceutiques, dont les contributions sont mentionnées dans les comptes-rendus pertinents. Mais ce sont les participants qui, en fin de compte, permettent aux conférences de maintenir leur seuil de rentabilité.

\section{État actuel de la recherche sur les mécanismes des anesthésiques généraux}

$\mathrm{Au}$ cours des quatre dernières décennies, les bases scientifiques des mécanismes de l'anesthésie ont évolué de façon spectaculaire, des controverses de Meyer-Overton à l'orthodoxie des récepteurs $\mathrm{GABA}_{\mathrm{A}}$, à une prise de conscience plus sage qu'il n'existe pas d'hypothèse unique au niveau moléculaire. Ceci n'est pas surprenant. Même les médicaments qui agissent à des concentrations nanomolaires possèdent des cibles secondaires; dès lors, les médicaments anesthésiques, dont la plupart agissent à des concentrations micromolaires, possèdent probablement plusieurs cibles. En effet, les observations quotidiennes des cliniciens quant à la physiologie de leurs patients appuient cette hypothèse. 
$\mathrm{Au}$ niveau moléculaire, les chercheurs font des progrès dans la connaissance des canaux. Le photo-étiquetage et la mutagenèse orientée vers un site ont été utilisés afin de localiser les sites de liaison et de comprendre l'interaction allostérique entre les anesthésiques généraux et l'activation des canaux pour certaines cibles. Au cours des deux dernières conférences MAC, la structure des canaux ioniques sensibles à un ligand a été révélée, et la liaison des anesthésiques aux canaux ioniques a été observée pour la première fois grâce à la cristallographie. Simultanément, des souris avec des canaux ioniques génétiquement modifiés ont été utilisées pour démontrer le lien entre le moléculaire et le physiologique, du moins pour les agents intraveineux les plus puissants. Les agents moins puissants se sont avérés moins faciles à élucider, peut-être parce que leur action est distribuée entre plusieurs cibles, ce qui constitue un défi constant à une meilleure compréhension des mécanismes d'action au niveau moléculaire.

Des progrès ont également été accomplis au-delà du niveau cellulaire étant donné que les physiologistes exploitent leurs connaissances des comportements des canaux afin d'approfondir leur compréhension des comportements des réseaux lors d'une anesthésie. La progression de notre compréhension des réseaux individuels précédera vraisemblablement une compréhension globale de la question plus importante, soit la conscience. La recherche quant à la manière dont les anesthésiques annihilent la conscience demeure active, mais elle est freinée par l'absence de définition physiologique de la conscience. Étant donné que nous croyons désormais que différentes classes d'anesthésiques généraux agissent sur différents types de récepteurs et de canaux, nous ne pouvons plus être certains que l'inconscience provoquée par les anesthésiques est un état unique. Face à de telles énigmes, certains chercheurs se sont tournés vers des entités quantifiables, tels que le sommeil et la mémoire. Il est clair que ce domaine de recherche gardera une importance capitale au cours des décennies à venir.

L'inquiétude quant aux actions délétères des anesthésiques généraux a fait son entrée en force dans les discussions qui se sont tenues lors de la conférence de 2010. D'un point de vue pratique, la sécurité du patient dépend bien plus des effets des anesthésiques généraux autres que leur capacité à induire une anesthésie. L'anesthésie n'est sécuritaire que parce qu'elle est prodiguée par un professionnel extrêmement bien formé dont le rôle premier est d'administrer une anesthésie. En soi, les agents ont des indices thérapeutiques épouvantables. Par exemple, il est probablement plus important de comprendre les mécanismes d'une détresse respiratoire provoquée par l'anesthésie que de comprendre comment fonctionne la conscience. En effet, un nouveau domaine de recherche a vu le jour et prend de l'envergure en raison des inquiétudes liées au fait que les anesthésiques généraux peuvent provoquer différentes formes de dysfonctionnement cognitif ou pourraient avoir des effets négatifs sur le cerveau en développement. Nous ne savons pas si ces effets sont provoqués par l'anesthésie ou la chirurgie, mais les implications sont tellement vastes que des recherches supplémentaires seront menées.

\section{Perspectives d'avenir}

Les attentes des patients et des médecins ont évolué, même si la mortalité liée à l'anesthésie n'a pas changé au cours des dernières décennies. Aujourd'hui, les patients prennent pour acquis qu'ils se réveilleront après une anesthésie sans garder aucun souvenir de l'intervention et que leurs fonctions physiologiques se rétabliront normalement. C'est pourquoi une meilleure compréhension des mécanismes d'action des anesthésiques généraux aux niveaux moléculaire et cellulaire est essentielle si l'on souhaite comprendre les mécanismes hors cible qui pourraient avoir des implications immédiates au niveau translationnel. Dans le même temps, nous sommes sur le point d'intégrer les connaissances acquises au niveau moléculaire afin de mieux comprendre le comportement du réseau neuronal. De telles perspectives nous rapprochent d'une compréhension de la base cellulaire de la conscience, ce qui pourrait nous permettre, un jour, de mieux surveiller la profondeur de l'anesthésie. Cette série de conférences attire autant de chercheurs professionnels que de cliniciens chercheurs et convient parfaitement aussi bien au but à long terme d'une augmentation des connaissances qu'aux questions translationnelles plus pressantes auxquelles la pratique clinique est actuellement confrontée.

Les recherches concernant les mécanismes d'action présentées lors de la conférence MAC 2010 remplissent trois rôles importants. En premier lieu, elles ont pour but de nous faire progresser dans la mise au point de médicaments en identifiant des récepteurs thérapeutiques clés ainsi que les sites d'action hors cible. Ceci fournira une base pour pouvoir mettre au point des agents anesthésiques innovants possédant des indices thérapeutiques plus élevés, le prochain obstacle aux progrès en matière de sécurité anesthésique. Deuxièmement, les études sur les mécanismes garantissent que nous tirons le plus de profit possible de l'utilisation clinique des anesthésiques actuellement disponibles en comprenant mieux leur action sur des cibles, thérapeutiques ou autres. Enfin, les anesthésiques demeurent des sondes puissantes qui peuvent être utilisées pour perturber de façon réversible les neurones et les réseaux, ce qui nous permettra de mieux comprendre la biologie du système nerveux central. 
Malgré les importants progrès présentés à Toronto, il y a encore beaucoup de travail à accomplir. Les patients s'attendent à ce que le meilleur de la science soit appliqué afin de résoudre les problèmes cliniques liés à l'anesthésie. La responsabilité de répondre à ces attentes incombe aux départements universitaires d'anesthésie, qui doivent continuer de former de nouveaux chercheurs et chercheurs cliniciens afin que les problèmes auxquels sont confrontés les patients soient abordés en science fondamentale. Le défi de ces départements sera de trouver les ressources nécessaires pour soutenir ces chercheurs et créer un environnement propice à la poursuite de la connaissance et de l'innovation.

Competing interests None declared.

\section{References}

1. Epstein RM. ASA Award: B. Raymond Fink. Anesthesiology 1987; 67: 456-8.

2. McGoldrick KE. B. Raymond Fink, M.D (1914-2000). Survey of Anesthesiology 2001; 45: 1-2.
3. Brown BR Jr. Book review: Molecular mechanisms of anesthesia: progress in anesthesiology. Anesth Analg 1981; 60: 366.

4. Roth SH, Miller KW, Fink BR (Editors). Molecular and Cellular Mechanisms of Anesthetics. New York: Plenum Medical Book Co.; 1986.

5. Fink BR (Editor). Molecular Mechanisms of Anesthesia. New York: Raven Press; 1975.

6. Fink BR (Editor) Molecular Mechanisms of Anesthesia. New York: Raven Press; 1980.

7. Fink BR. Mécanisms de la Narcose. Coll Internat. Paris: CNRS; 1951.

8. Fink BR. Toxicity of Anesthetics. Proceedings of a research symposium held in Seattle May 12-13, 1967. Edited by B.R. Fink. Baltimore: Williams \& Wilkins; 1968.

9. Fink BR. Cellular Biology and Toxicity of Anesthetics. Proceedings of a research symposium held in Seattle, May 11-12, 1970. Edited by B.R. Fink. Baltimore: Williams \& Wilkins; 1972.

10. Rubin E, Miller KW, Roth SH. Molecular and Cellular Mechanisms of Alcohol and Anesthetics. : New York Academy of Sciences; 1991.

11. Richards $C D$, Winlow $W$ (Editors). Toxicology Letters: Proceedings of the 5th International Conference on the Molecular and Cellular Mechanisms of Anesthesia; 1998.

12. Urban BW, Barann M. Molecular and Basic Mechanisms of Anesthesia. Lengerich; Miami: Pabst Science Publishers; 2002.

13. Miller $K W$, Richards $C D$, Roth $S H$, Urban BW. Molecular and basic mechanisms of anaesthesia. Br J Anaesth 2002; 89: 1-2.

14. Mashimo T, Ogli K, Uchida I. Basic and Systemic Mechanisms of Anesthesia. Amsterdam, the Netherlands: Elsevier; 2005. 